\title{
Survival from twenty adult cancers in the UK and Republic of Ireland in the late twentieth century
}

Laura M Woods ${ }^{1 *}$, Bernard Rachet ${ }^{1}$, Lorraine Shack ${ }^{2}$, Denise Catney ${ }^{3}$, Paul M Walsh ${ }^{4}$, Nicola Cooper $^{5}$, Ceri White ${ }^{6}$, Vivian Mak ${ }^{7}$, John Steward ${ }^{6}$, Harry Comber ${ }^{4}$, Anna Gavin ${ }^{3}$, David Brewster $^{2}$, Mike Quinn ${ }^{5}$, Michel P Coleman ${ }^{1}$ and the UK Association of Cancer Registries

${ }^{*}$ Corresponding author: Laura Woods (laura.woods@Ishtm.ac.uk)

Authors' affiliations:

${ }^{1}$ Cancer Research UK Cancer Survival Group, Non-Communicable Disease Epidemiology Unit, London School of Hygiene and Tropical Medicine, Keppel Street, London, WC1E 7HT, UK

${ }^{2}$ Scottish Cancer Registry, Information Services Division of NHS National Services Scotland (ISD Scotland), Area 155, Gyle Square, 1 South Gyle Crescent, Edinburgh, EH12 9EB, UK

${ }^{3}$ Northern Ireland Cancer Registry, Centre for Clinical and Population Sciences, Queen's University Belfast, Mulhouse Building, Grosvenor Road, Belfast, BT12 6BJ, UK

${ }^{4}$ National Cancer Registry, Ireland, Building 6800, Cork Airport Business Park, Kinsale Road, Cork, Ireland

${ }^{5}$ Office for National Statistics, FG/119, 1 Myddelton Street, London EC1R 1UW, UK

${ }^{6}$ Wales Cancer Intelligence and Surveillance Unit, 13th Floor, Brunel House, 2 Fitzalan Road, Cardiff CF24 OHA, UK

${ }^{7}$ King's College London, Thames Cancer Registry, 1st Floor Capital House, 42 Weston Street, London SE1 3QD, UK 


\begin{abstract}
Background

International studies have shown that cancer survival was generally low in the UK and the Republic of Ireland compared to western and northern European countries, but no systematic comparative analysis has been performed between the UK countries and the Republic of Ireland.
\end{abstract}

Methods

Population-based survival for $\mathbf{2 0}$ adult malignancies was estimated for the UK and the Republic of Ireland. Data on adults (15-99 years) diagnosed between 1991 and 1999 in England, Scotland, Wales, Northern Ireland (1993-99) and the Republic of Ireland (1994-99) were analysed. All cases were followed up until the end of 2001. Relative survival was estimated by sex, period of diagnosis and country, and for the nine regions of England. Predicted survival was estimated using the hybrid approach.

Results

Overall, cancer survival in UK and Republic of Ireland improved during the 1990s, but there was geographic variation in survival across the UK and Republic of Ireland. Survival was generally highest in Ireland and Northern Ireland and lowest in England and Wales. Survival tended to be higher in Scotland for cancers for which early detection methods were in place. In England, survival tended to be lower in the north and higher in the south.

\title{
Conclusions
}

The geographic variations in survival seen across the UK and Republic of Ireland are narrower than between these countries and comparable European countries. Artefact is likely to explain some, but not all of the differences across the UK and Republic of Ireland. Geographic differences in stage at diagnosis, co-morbidity and other clinical factors may also be relevant. 


\section{Contents}

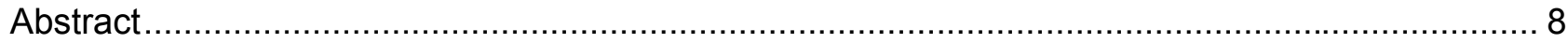

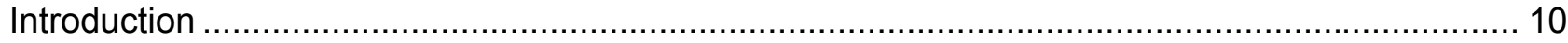

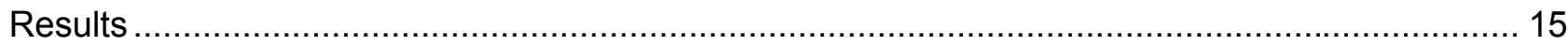

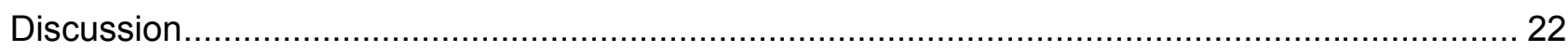

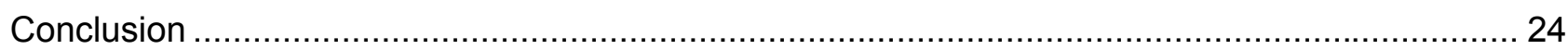

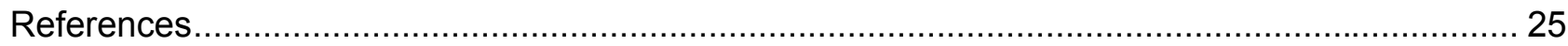

\section{List of Figures}

Figure 1 Structure of data used for survival analyses.

Figure 2 Range in one-year relative survival (\%) by country, for (a) cancers with good prognosis (one-year survival $50 \%$ or higher) and (b) cancers with poor prognosis (one-year survival less than 50\%): patients diagnosed in the UK and Republic of Ireland 1996-99.

Figure 3 Funnel plots showing the geographical variation in one-year relative survival for patients diagnosed during 1996-99 in the UK and Republic of Ireland: selected cancers

\section{List of Tables}

Table 1 Exclusions (\% of eligible patients) and number and percentage of all eligible cases included in the survival analyses: cancer patients diagnosed during 1991-99 in the United Kingdom and the Republic of Ireland

Table 2 Five-year relative survival (\%), with 95\% confidence interval $(\mathrm{Cl})$, for patients diagnosed 1996-99, mean annual change (\%), between 1996-99 and 1991-95 and predictions of five-year survival for patients diagnosed 2000-01 (with $95 \% \mathrm{Cl}$ ), by country, sex and site: UK and Republic of Ireland 


\section{Introduction}

Population-based cancer survival data are available for patients diagnosed since 1971 for England and Wales (Coleman et al. 1999;Coleman et al. 2004) and for Scotland (Scottish Cancer Intelligence Unit 2000), but only since 1993 for Northern Ireland (Northern Ireland Cancer Registry 2007) and 1994 for the Republic of Ireland (Comber \& Walsh 2008) It is not possible to evaluate geographical differences in cancer survival in the UK and the Republic of Ireland directly from these data, because of methodological differences between the various analyses. Survival estimates for the UK have not routinely been produced. Substantial regional variation in cancer survival has been demonstrated in England (Coleman et al. 1999) but this variation has not been directly compared with differences between the four countries of the UK or with the Republic of Ireland.

Here we examine cancer survival in the Republic of Ireland and the UK, for each of the four UK nations separately, and for all five countries combined. We also examine variation in survival between the nine Government Office Regions of England.

\section{Methods and data}

All persons diagnosed with one of the 20 most common cancers during the period 1991-99 in England, Scotland, Wales, 1993-99 in Northern Ireland and 1994-99 in the Republic of Ireland were eligible for inclusion. Anonymised individual records were obtained from the national cancer registries of each country. We analysed the survival of more than 1.7 million patients aged 15-99 years, 86 per cent of those were eligible for inclusion (Table 1). Follow-up was complete to 31 December 2001. Nine per cent of patients were excluded because their recorded survival time was zero, mainly patients registered from a death certificate only (DCO), whose survival time was unknown. The proportion was greater in England and Wales than in Scotland, Northern Ireland and the Republic of Ireland. A further five per cent of patients were excluded because it was not their first cancer, or for other reasons, including unknown vital status. Non-melanoma skin cancers were not considered because their registration was too patchy in the UK during the study period. 
Table 1 Exclusions (\% of eligible patients) and number and percentage of all eligible cases included in the survival analyses: cancer patients diagnosed during $1991-99^{\mathrm{a}}$ in the United Kingdom and the Republic of Ireland

\begin{tabular}{|c|c|c|c|c|c|c|c|c|}
\hline \multirow[b]{3}{*}{ Malignancy } & \multicolumn{4}{|c|}{ England } & \multicolumn{4}{|c|}{ Scotland } \\
\hline & \multicolumn{2}{|c|}{$\begin{array}{c}\text { Exclusions } \\
\text { ( } \% \text { of eligible) }\end{array}$} & \multicolumn{2}{|c|}{$\begin{array}{l}\text { Eligible cases } \\
\text { analysed }\end{array}$} & \multicolumn{2}{|c|}{$\begin{array}{l}\text { Exclusions } \\
\text { (\% of eligible) }\end{array}$} & \multicolumn{2}{|c|}{$\begin{array}{l}\text { Eligible cases } \\
\text { analysed }\end{array}$} \\
\hline & $\begin{array}{r}\text { Zero } \\
\text { survival }^{b}\end{array}$ & Other & No. & $\%$ & $\begin{array}{r}\text { Zero } \\
\text { survival }^{\mathbf{b}}\end{array}$ & Other & No. & $\%$ \\
\hline Oesophagus & 9.5 & 4.9 & 42,464 & 85.6 & 3.1 & 7.5 & 6,113 & 89.5 \\
\hline Stomach & 12.4 & 4.5 & 65,108 & 83.2 & 4.8 & 6.5 & 8,085 & 88.7 \\
\hline Colon & 10.2 & 5.6 & 132,514 & 84.2 & 3.7 & 7.9 & 17,266 & 88.4 \\
\hline Rectum & 5.8 & 5.2 & 79,828 & 89.0 & 2.2 & 7.2 & 9,307 & 90.6 \\
\hline Pancreas & 21.4 & 4.0 & 38,587 & 74.6 & 9.3 & 6.4 & 4,630 & 84.3 \\
\hline Larynx (M) & 4.0 & 22.3 & 12,290 & 73.7 & 1.4 & 8.1 & 1,963 & 90.5 \\
\hline Lung & 14.9 & 4.8 & 236,500 & 80.3 & 6.4 & 7.2 & 36,885 & 86.5 \\
\hline Melanoma of skin & 2.1 & 5.1 & 38,535 & 92.8 & 0.2 & 7.1 & 4,974 & 92.7 \\
\hline Breast (F) & 5.2 & 5.9 & 252,467 & 88.8 & 2.2 & 6.5 & 27,053 & 91.4 \\
\hline Cervix & 3.6 & 6.1 & 23,736 & 90.3 & 0.8 & 7.6 & 3,103 & 91.6 \\
\hline Uterus & 5.0 & 7.8 & 33,297 & 87.2 & 2.3 & 10.1 & 3,388 & 87.6 \\
\hline Ovary & 9.3 & 5.3 & 40,683 & 85.4 & 2.5 & 7.6 & 4,903 & 89.9 \\
\hline Prostate & 7.6 & 4.7 & 145,946 & 87.7 & 3.1 & 6.5 & 14,691 & 90.5 \\
\hline Testis & 0.8 & 2.8 & 12,460 & 96.4 & 0.2 & 1.6 & 1,569 & 98.2 \\
\hline Bladder & 5.0 & 6.4 & 87,431 & 88.7 & 1.3 & 9.5 & 9,886 & 89.2 \\
\hline Kidney & 11.2 & 6.8 & 33,386 & 82.0 & 5.3 & 10.2 & 4,365 & 84.5 \\
\hline Brain & 9.1 & 3.7 & 24,506 & 87.2 & 3.6 & 3.9 & 2,702 & 92.5 \\
\hline Non-Hodgkin lymphoma & 8.3 & 5.0 & 54,046 & 86.7 & 3.0 & 7.0 & 6,313 & 90.0 \\
\hline Multiple myeloma & 11.5 & 4.5 & 21,553 & 84.1 & 3.7 & 7.1 & 2,407 & 89.2 \\
\hline All leukaemias & 14.6 & 5.9 & 37,865 & 79.5 & 5.0 & 7.9 & 4,501 & 87.1 \\
\hline Total & 9.3 & 5.5 & $1,413,202$ & 85.2 & 3.8 & 7.3 & 174,104 & 89.0 \\
\hline
\end{tabular}




\section{Table 1 continued}

\begin{tabular}{|c|c|c|c|c|c|c|c|c|}
\hline \multirow[b]{3}{*}{ Malignancy } & \multicolumn{4}{|c|}{ Wales } & \multicolumn{4}{|c|}{ Northern Ireland ${ }^{a}$} \\
\hline & \multicolumn{2}{|c|}{$\begin{array}{l}\text { Exclusions } \\
\text { (\% of eligible) }\end{array}$} & \multicolumn{2}{|c|}{$\begin{array}{l}\text { Eligible cases } \\
\text { analysed }\end{array}$} & \multicolumn{2}{|c|}{$\begin{array}{l}\text { Exclusions } \\
\text { (\% of eligible) }\end{array}$} & \multicolumn{2}{|c|}{$\begin{array}{l}\text { Eligible cases } \\
\text { analysed }\end{array}$} \\
\hline & $\begin{array}{r}\text { Zero } \\
\text { survival }\end{array}$ & Other & No. & $\%$ & $\begin{array}{r}\text { Zero } \\
\text { survival }^{b}\end{array}$ & Other & No. & $\%$ \\
\hline Oesophagus & 10.9 & 4.2 & 2,927 & 85.0 & 3.7 & 3.9 & 993 & 92.4 \\
\hline Stomach & 15.2 & 3.7 & 5,236 & 81.0 & 4.6 & 3.0 & 1,696 & 92.4 \\
\hline Colon & 12.6 & 3.5 & 9,393 & 84.0 & 4.3 & 2.7 & 4,064 & 93.0 \\
\hline Rectum & 6.5 & 3.3 & 5,885 & 90.2 & 1.2 & 3.8 & 2,056 & 95.0 \\
\hline Pancreas & 21.1 & 3.7 & 2,670 & 75.2 & 6.8 & 3.0 & 925 & 90.2 \\
\hline Larynx (M) & 4.4 & 24.9 & 888 & 70.7 & 0.4 & 6.1 & 361 & 93.5 \\
\hline Lung & 18.4 & 5.8 & 15,026 & 75.8 & 5.0 & 2.8 & 5,755 & 92.2 \\
\hline Melanoma of skin & 3.9 & 6.5 & 2,081 & 89.5 & 0.2 & 2.4 & 1,193 & 97.5 \\
\hline Breast (F) & 5.6 & 4.7 & 17,348 & 89.7 & 1.5 & 1.0 & 5,866 & 97.5 \\
\hline Cervix & 4.8 & 7.7 & 1,630 & 87.5 & 1.4 & 1.7 & 564 & 96.9 \\
\hline Uterus & 7.2 & 5.7 & 2,457 & 87.1 & 3.7 & 4.4 & 767 & 91.9 \\
\hline Ovary & 8.0 & 6.1 & 2,920 & 85.9 & 2.1 & 5.5 & 1,090 & 92.4 \\
\hline Prostate & 7.7 & 4.1 & 9,825 & 88.3 & 2.9 & 2.6 & 3,175 & 94.6 \\
\hline Testis & 1.4 & 3.0 & 735 & 95.6 & 0.3 & 0.9 & 342 & 98.8 \\
\hline Bladder & 4.0 & 6.5 & 6,654 & 89.4 & 1.6 & 6.6 & 1,357 & 91.8 \\
\hline Kidney & 11.3 & 6.2 & 2,395 & 82.5 & 2.8 & 6.1 & 1,013 & 91.1 \\
\hline Brain & 9.3 & 5.0 & 1,808 & 85.8 & 2.3 & 1.4 & 633 & 96.3 \\
\hline Non-Hodgkin lymphoma & 7.7 & 6.8 & 3,389 & 85.5 & 2.9 & 3.2 & 1,567 & 93.9 \\
\hline Multiple myeloma & 11.3 & 5.6 & 1,422 & 83.1 & 2.9 & 3.2 & 625 & 94.0 \\
\hline All leukaemias & 10.5 & 6.4 & 3,157 & 83.1 & 3.7 & 2.0 & 935 & 94.3 \\
\hline Total & 10.3 & 5.2 & 97,846 & 84.5 & 3.1 & 2.9 & 34,977 & 94.0 \\
\hline
\end{tabular}




\section{Table 1 continued}

\begin{tabular}{|c|c|c|c|c|c|c|c|c|}
\hline \multirow[b]{3}{*}{ Malignancy } & \multicolumn{4}{|c|}{ Republic of Ireland ${ }^{a}$} & \multicolumn{4}{|c|}{ UK and Republic of Ireland ${ }^{a}$} \\
\hline & \multicolumn{2}{|c|}{$\begin{array}{l}\text { Exclusions } \\
\text { (\% of eligible) }\end{array}$} & \multicolumn{2}{|c|}{$\begin{array}{l}\text { Eligible cases } \\
\text { analysed }\end{array}$} & \multicolumn{2}{|c|}{$\begin{array}{c}\text { Exclusions } \\
\text { ( } \% \text { of eligible) }\end{array}$} & \multicolumn{2}{|c|}{$\begin{array}{l}\text { Eligible cases } \\
\text { analysed }\end{array}$} \\
\hline & $\begin{array}{r}\text { Zero } \\
\text { survival }^{b}\end{array}$ & Other ${ }^{c}$ & No. & $\%$ & $\begin{array}{r}\text { Zero } \\
\text { survival }\end{array}$ & Other & No. & $\%$ \\
\hline Oesophagus & 3.9 & 1.8 & 1,696 & 94.3 & 8.6 & 5.0 & 54,193 & 86.4 \\
\hline Stomach & 5.6 & 2.2 & 2,693 & 92.1 & 11.5 & 4.5 & 82,818 & 84.0 \\
\hline Colon & 4.7 & 2.7 & 6,290 & 92.6 & 9.4 & 5.5 & 169,527 & 85.1 \\
\hline Rectum & 1.9 & 3.2 & 3,750 & 94.9 & 5.3 & 5.2 & 100,826 & 89.5 \\
\hline Pancreas & 8.3 & 2.1 & 1,837 & 89.6 & 19.7 & 4.1 & 48,649 & 76.2 \\
\hline Larynx (M) & 2.5 & 1.5 & 531 & 96.0 & 3.7 & 20.1 & 16,033 & 76.2 \\
\hline Lung & 6.5 & 1.8 & 8,587 & 91.7 & 13.7 & 5.0 & 302,753 & 81.2 \\
\hline Melanoma of skin & 0.1 & 2.7 & 2,232 & 97.3 & 1.8 & 5.2 & 49,015 & 93.0 \\
\hline Breast (F) & 1.8 & 1.2 & 9,599 & 97.1 & 4.8 & 5.7 & 312,333 & 89.5 \\
\hline Cervix & 2.0 & 1.5 & 1,024 & 96.5 & 3.3 & 6.1 & 30,057 & 90.6 \\
\hline Uterus & 2.6 & 3.0 & 1,319 & 94.4 & 4.8 & 7.6 & 41,228 & 87.5 \\
\hline Ovary & 3.5 & 3.7 & 1,823 & 92.8 & 8.3 & 5.5 & 51,419 & 86.2 \\
\hline Prostate & 3.3 & 2.2 & 7,050 & 94.5 & 7.0 & 4.7 & 180,687 & 88.3 \\
\hline Testis & 0.5 & 0.0 & 548 & 99.5 & 0.7 & 2.5 & 15,654 & 96.7 \\
\hline Bladder & 2.1 & 4.0 & 2,628 & 93.9 & 4.5 & 6.6 & 107,956 & 88.9 \\
\hline Kidney & 5.8 & 4.5 & 1,481 & 89.7 & 10.2 & 7.0 & 42,640 & 82.8 \\
\hline Brain & 4.6 & 1.0 & 1,302 & 94.3 & 8.4 & 3.6 & 30,951 & 88.0 \\
\hline Non-Hodgkin lymphoma & 2.9 & 1.7 & 2,278 & 95.4 & 7.5 & 5.1 & 67,593 & 87.4 \\
\hline Multiple myeloma & 4.5 & 2.1 & 1,016 & 93.4 & 10.4 & 4.6 & 27,023 & 85.0 \\
\hline All leukaemias & 3.8 & 2.4 & 1,841 & 93.8 & 13.0 & 5.9 & 48,299 & 81.1 \\
\hline Total & 3.8 & 2.2 & 59,525 & 94.0 & 8.6 & 5.5 & $1,779,654$ & 86.0 \\
\hline
\end{tabular}

${ }^{a}$ Incident cases in Northern Ireland were diagnosed 1993-99, and in the Republic of Ireland 1994-99.

${ }^{b}$ Date of diagnosis same as date of death: some patients did die on the day of diagnosis, but most were registered solely from a death certificate, with unknown survival time.

${ }^{c}$ Aged 100 years or over at diagnosis, vital status or sex unknown, sex-site error, invalid dates, duplicate registration, synchronous tumour or persons who had a previous primary malignancy.

We examined relative survival from cancer. Relative survival is one method of estimating net survival, which is the probability of survival related directly to the disease rather than the overall observed (crude) survival of the patient group. Relative survival is estimated by comparing the observed survival with the survival that would have been expected if the patients had only experienced the expected (or background) mortality by age and sex as that seen in the general population in the same country or region and calendar year. The expected mortality is given by general population life tables of all-cause mortality by the same variables. Relative survival is the most defensible method of estimating net survival in population-based studies, because it does not rely upon accurate reporting of cause of death (Ederer, Axtell, \& Cutler 1961). 
We used the maximum-likelihood approach for individual records (Estève et al. 1990) as implemented in the publicly available STATA algorithm strel to estimate the excess hazard of death from cancer for given time intervals after diagnosis. For any given cancer and a given sex, we used a constant interval structure to divide the follow-up time, but varied the number of intervals from 4 to 14 for different cancers according to the number of cases and the observed pattern of mortality. Cumulative relative survival up to five years after diagnosis was estimated by age group and country, using either the cohort or complete approach, for patients diagnosed during 1991-95 and 1996-99. We applied the hybrid approach (Brenner \& Rachet 2004) to predict relative survival in the near future, using data for patients who were alive and under follow-up at some point during the period 2000-01 (Figure 1). The mean annual absolute percentage change in relative survival between 1991-95 and 1996-99 was estimated with variance-weighted least squares regression, taking into account the slightly shorter periods of incidence available for Northern Ireland (199395) and the Republic of Ireland (1994-95).

\section{Figure 1 Structure of data used for survival analyses}

\begin{tabular}{|c|c|c|c|c|c|c|c|c|c|c|c|c|c|}
\hline & & \multirow[b]{2}{*}{ Countries } & \multicolumn{11}{|c|}{ Calendar years within which follow-up probabilities are used to estimate survival } \\
\hline & & & 1991 & 1992 & 1993 & 1994 & 1995 & 1996 & 1997 & 1998 & 1999 & 2000 & 2001 \\
\hline \multirow{5}{*}{ 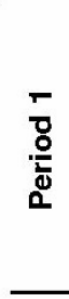 } & 1991 & EN, WA \& SC & 0 & $\overline{1}$ & 2 & 3 & $\overline{4}$ & 5 & 6 & 7 & 8 & 9 & 10 \\
\hline & 1992 & EN, WA \& SC & & 0 & 1 & 2 & 3 & 4 & 5 & 6 & 7 & 8 & 9 \\
\hline & 1993 & UK & & & 0 & 1 & 2 & 3 & 4 & 5 & 6 & 7 & 8 \\
\hline & 1994 & UK \& RI & \multirow{2}{*}{\multicolumn{3}{|c|}{$\begin{array}{l}\text { Survival data used } \\
\text { in cohort analysis }\end{array}$}} & 0 & 1 & 2 & 3 & 4 & 5 & 6 & 7 \\
\hline & 1995 & UK \& RI & & & & & 0 & 1 & 2 & 3 & 4 & 5 & 6 \\
\hline \multirow{4}{*}{ 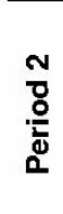 } & 1996 & UK \& RI & & & \multirow{4}{*}{\multicolumn{2}{|c|}{$\begin{array}{l}\text { Survival data } \\
\text { in complete an }\end{array}$}} & used & 0 & 1 & 2 & 3 & 4 & 5 \\
\hline & 1997 & UK \& RI & & & & & alysis & & 0 & 1 & 2 & 3 & 4 \\
\hline & 1998 & UK \& RI & & & & & \multirow{2}{*}{\multicolumn{3}{|c|}{$\begin{array}{l}\text { Survival data used } \\
\text { in hybrid analysis }\end{array}$}} & 0 & 1 & 2 & 3 \\
\hline & 1999 & UK \& RI & & & & & & & & & 0 & 1 & 2 \\
\hline
\end{tabular}

Numeric values indicate the minimum number of completed years of follow-up attained for an individual diagnosed during the index year (rows) who was followed up to the end of a given calendar year (columns).

UK - United Kingdom, SC - Scotland, WA - Wales, RI - Republic of Ireland

National or regional life tables were used to estimate expected survival. For the national analyses, the Government Actuary's Department (GAD) interim life tables centred on 1991 and 1996 were used for each country in the UK (Government Actuary's Department 2004). For the Republic of Ireland, census-derived life tables centred on these same two years were used (Central Statistics Office 1995, 2004). Background mortality for patients dying during the period 1991-95 was represented by the 1991 life tables, whilst the 1996 tables were used for patients dying during the period 1996-01. Regional analyses for England were conducted using 1991 and 1998-centred region-specific life tables, described elsewhere (Coleman et al. 1999; Coleman et al. 2004). The "observed" background mortality rates are unstable and usually not available for every year of age for elderly. All life tables were therefore smoothed and extended up to 100 years of age with the 
Ewbank et al. four-parameter life table system (Ewbank et al. 1983) constrained to three independent parameters.

To improve the comparability of the results, an attempt was made to age-standardise the survival estimates directly with age weights derived from the numbers of patients diagnosed with each cancer in England and Wales during the period 1986-90 (Coleman et al. 1999). Three broad age groups were used: under 50,50-69 and 70 or more years at diagnosis. Finer age groups could not be applied because of the small numbers of cases and deaths in the data sets for the Republic of Ireland, Northern Ireland and Wales, and in some of the English regions. Even so, it was often impossible to produce an age-standardised estimate. Age-standardised and non-standardised estimates were very similar when both were available (data available on request), and only nonstandardised rates are presented here.

We used funnel plots to examine geographic variation in one-year survival between the English regions and the other four countries (Spiegelhalter 2005). One-year survival was used because an estimate was available for every country for every malignancy. For each region or country, the estimate of one-year survival is plotted against the precision of the estimate, taken as the inverse square of its standard error. The horizontal line in each plot, the target value, is the pooled estimate of one-year survival in the UK and the Republic of Ireland combined. The 95 per cent and 99.8 per cent control limits superimposed on each plot represent approximately two and three standard deviations, respectively, from the target value at each level of precision. Survival estimates that lie within the control limits may be considered as within the geographical variation that could be expected by chance. Funnel plots may be preferable to conventionally ranked bar charts for visual comparison of a set of estimates with widely different precision.

\section{Results}

Relative survival from the twenty most common cancers generally increased between the early and late 1990s, both in the constituent countries of the UK and in the Republic of Ireland. Cancer survival, and improvements in survival, varied between the five countries (Table 2, Figures 2 and 3 ). Details of the numbers of patients included in the analyses, the numbers of deaths and estimates of survival at one and five years for each cancer and each calendar period are available online as Supplementary Tables 1 and 2. Survival also varied between the regions of England (Supplementary Figure 1, Supplementary Tables 3, 4 and 5). 
Table 2

Five-year relative survival (\%), with $95 \%$ confidence interval (Cl), for patients diagnosed 1996-99, mean annual change $(\%)^{a}$, between 1996-99 and 1991-95 and predictions of fiveyear survival for patients diagnosed 2000-01 (with 95\% Cl), by country, sex and site: UK and Republic of Ireland

\begin{tabular}{|c|c|c|c|c|c|c|c|c|c|c|c|c|c|}
\hline \multirow{3}{*}{ Malignancy } & \multirow{3}{*}{ Sex } & \multicolumn{6}{|c|}{ England } & \multicolumn{6}{|c|}{ Scotland } \\
\hline & & \multicolumn{2}{|c|}{$\begin{array}{l}1996-99 \\
\text { complete }\end{array}$} & \multirow{2}{*}{\multicolumn{2}{|c|}{$\begin{array}{l}\text { Annual \% } \\
\text { change }^{\mathrm{a}}\end{array}$}} & \multicolumn{2}{|c|}{$\begin{array}{c}2000-2001 \\
\text { hybrid }\end{array}$} & \multicolumn{2}{|c|}{$\begin{array}{c}1996-99 \\
\text { complete }\end{array}$} & \multicolumn{2}{|c|}{$\begin{array}{c}\text { Annual \% } \\
\text { change }^{\mathrm{a}}\end{array}$} & \multicolumn{2}{|c|}{$\begin{array}{c}2000-2001 \\
\text { hybrid }\end{array}$} \\
\hline & & $R S$ & $(C l)$ & & & $R S$ & $(C l)$ & $R S$ & $(\mathrm{Cl})$ & & & $R S$ & $(C l)$ \\
\hline \multirow[t]{2}{*}{ Oesophagus } & M & 8 & $(7 ; 9)$ & 0.3 & * & 8 & $(8 ; 9)$ & 10 & $(9 ; 12)$ & 0.6 & * & 10 & $(8 ; 13)$ \\
\hline & $\mathrm{F}$ & 7 & $(7 ; 8)$ & $<-0.1$ & & 8 & $(7 ; 9)$ & 9 & $(7 ; 12)$ & 0.2 & & 9 & $(7 ; 12)$ \\
\hline \multirow[t]{2}{*}{ Stomach } & M & 14 & $(13 ; 14)$ & 0.5 & * & 14 & $(13 ; 15)$ & 14 & $(12 ; 16)$ & 0.5 & & 13 & $(11 ; 16)$ \\
\hline & $\mathrm{F}$ & 14 & $(14 ; 15)$ & 0.5 & * & 15 & $(14 ; 16)$ & 15 & $(13 ; 17)$ & 0.4 & & 16 & $(13 ; 19)$ \\
\hline \multirow[t]{2}{*}{ Colon } & M & 49 & $(48 ; 50)$ & 1.2 & * & 50 & $(49 ; 51)$ & 50 & $(47 ; 52)$ & 0.6 & & 51 & $(48 ; 54)$ \\
\hline & $F$ & 48 & $(47 ; 49)$ & 1.1 & * & 49 & $(48 ; 50)$ & 51 & $(49 ; 53)$ & 0.9 & * & 53 & $(50 ; 55)$ \\
\hline \multirow[t]{2}{*}{ Rectum } & M & 51 & $(50 ; 52)$ & 1.9 & * & 53 & $(51 ; 54)$ & 51 & $(48 ; 54)$ & 1.6 & * & 54 & $(50 ; 58)$ \\
\hline & $\mathrm{F}$ & 51 & $(50 ; 53)$ & 1.5 & * & 52 & $(51 ; 53)$ & 53 & $(50 ; 56)$ & 1.4 & * & 54 & $(49 ; 58)$ \\
\hline \multirow[t]{2}{*}{ Pancreas } & M & 3 & $(3 ; 3)$ & 0.1 & * & 3 & $(3 ; 4)$ & 3 & $(2 ; 4)$ & $<-0.1$ & & 3 & $(2 ; 6)$ \\
\hline & $\mathrm{F}$ & 2 & $(2 ; 3)$ & $<-0.1$ & & 2 & $(2 ; 3)$ & 3 & $(2 ; 4)$ & -0.2 & & 4 & $(2 ; 6)$ \\
\hline Larynx & $M$ & 67 & $(65 ; 68)$ & 0.5 & & 67 & $(64 ; 69)$ & 65 & $(60 ; 69)$ & 0.4 & & 64 & $(58 ; 70)$ \\
\hline \multirow[t]{2}{*}{ Lung } & M & 6 & $(6 ; 7)$ & 0.2 & * & 7 & $(6 ; 7)$ & 7 & $(7 ; 8)$ & $<-0.1$ & & 8 & $(7 ; 9)$ \\
\hline & $\mathrm{F}$ & 7 & $(7 ; 7)$ & 0.3 & * & 7 & $(7 ; 8)$ & 8 & $(7 ; 9)$ & 0.4 & * & 9 & $(8 ; 10)$ \\
\hline \multirow{2}{*}{$\begin{array}{l}\text { Melanoma } \\
\text { of skin }\end{array}$} & M & 80 & $(79 ; 82)$ & 1.0 & * & 81 & $(79 ; 83)$ & 85 & $(81 ; 88)$ & 0.8 & & 86 & $(81 ; 90)$ \\
\hline & $\mathrm{F}$ & 91 & $(90 ; 91)$ & 0.5 & * & 91 & $(90 ; 92)$ & 96 & $(93 ; 97)$ & 0.8 & * & 96 & $(93 ; 98)$ \\
\hline Breast & $\mathrm{F}$ & 81 & $(80 ; 81)$ & 1.0 & * & 82 & $(81 ; 82)$ & 80 & $(79 ; 81)$ & 0.8 & * & 81 & $(80 ; 83)$ \\
\hline Cervix & $\mathrm{F}$ & 67 & $(66 ; 68)$ & 0.2 & & 68 & $(66 ; 69)$ & 69 & $(66 ; 72)$ & 1.0 & * & 71 & $(66 ; 75)$ \\
\hline Uterus & $\mathrm{F}$ & 77 & $(76 ; 78)$ & 0.8 & * & 78 & $(77 ; 79)$ & 79 & $(76 ; 82)$ & 0.9 & * & 80 & $(76 ; 83)$ \\
\hline Ovary & $\mathrm{F}$ & 39 & $(38 ; 40)$ & 1.6 & * & 40 & $(38 ; 41)$ & 41 & $(39 ; 44)$ & 1.8 & * & 42 & $(39 ; 46)$ \\
\hline Prostate & M & 73 & $(73 ; 74)$ & 3.2 & * & 75 & $(74 ; 75)$ & 72 & $(70 ; 74)$ & 2.6 & * & 74 & $(72 ; 77)$ \\
\hline Testis & M & 96 & $(95 ; 97)$ & 0.3 & * & 96 & $(96 ; 97)$ & 98 & $(96 ; 99)$ & 0.7 & $*$ & 98 & $(94 ; 99)$ \\
\hline \multirow[t]{2}{*}{ Bladder } & $M$ & 69 & $(68 ; 70)$ & 0.2 & & 69 & $(67 ; 70)$ & 68 & $(65 ; 71)$ & -1.2 & $*$ & 62 & $(58 ; 66)$ \\
\hline & $\mathrm{F}$ & 57 & $(55 ; 58)$ & -0.5 & * & 57 & $(55 ; 59)$ & 55 & $(51 ; 58)$ & -1.7 & * & 48 & $(43 ; 53)$ \\
\hline \multirow{2}{*}{$\begin{array}{l}\text { Bladder includ. } \\
\text { non-malignant }\end{array}$} & $M$ & 70 & $(69 ; 71)$ & 0.3 & * & 70 & $(69 ; 71)$ & 66 & $(63 ; 68)$ & -1.6 & * & 59 & $(56 ; 63)$ \\
\hline & $\mathrm{F}$ & 58 & $(57 ; 60)$ & -0.4 & * & 59 & $(57 ; 61)$ & 54 & $(50 ; 58)$ & -1.8 & * & 47 & $(42 ; 52)$ \\
\hline \multirow[t]{2}{*}{ Kidney } & M & 48 & $(46 ; 49)$ & 0.8 & * & 49 & $(47 ; 50)$ & 44 & $(40 ; 48)$ & 0.4 & & 47 & $(42 ; 52)$ \\
\hline & $F$ & 46 & $(45 ; 48)$ & 1.2 & * & 47 & $(45 ; 49)$ & 48 & $(43 ; 52)$ & 1.6 & * & 50 & $(44 ; 55)$ \\
\hline \multirow[t]{2}{*}{ Brain } & M & 13 & $(12 ; 14)$ & -0.2 & & 12 & $(11 ; 13)$ & 16 & $(13 ; 20)$ & 0.1 & & 13 & $(10 ; 17)$ \\
\hline & $\mathrm{F}$ & 14 & $(13 ; 15)$ & -0.1 & & 14 & $(12 ; 15)$ & 16 & $(12 ; 19)$ & -0.5 & & 12 & $(9 ; 17)$ \\
\hline \multirow{2}{*}{$\begin{array}{l}\text { Non-Hodgkin } \\
\text { lymphoma }\end{array}$} & M & 54 & $(52 ; 55)$ & 1.1 & * & 55 & $(53 ; 56)$ & 56 & $(53 ; 59)$ & 1.9 & * & 57 & $(53 ; 62)$ \\
\hline & $F$ & 54 & $(53 ; 56)$ & 0.9 & * & 55 & $(54 ; 57)$ & 54 & $(50 ; 57)$ & 1.3 & $*$ & 56 & $(51 ; 60)$ \\
\hline \multirow{2}{*}{$\begin{array}{l}\text { Multiple } \\
\text { myeloma }\end{array}$} & M & 30 & $(28 ; 31)$ & 1.4 & * & 30 & $(28 ; 32)$ & 25 & $(19 ; 32)$ & $<-0.1$ & & 26 & $(19 ; 34)$ \\
\hline & $F$ & 27 & $(26 ; 29)$ & 1.3 & * & 28 & $(26 ; 30)$ & 31 & $(25 ; 37)$ & 1.3 & & 28 & $(22 ; 35)$ \\
\hline All leukaemias & $M$ & 45 & $(44 ; 46)$ & 1.1 & * & 45 & $(43 ; 47)$ & 51 & $(47 ; 55)$ & 1.9 & * & 53 & $(48 ; 58)$ \\
\hline & $\mathrm{F}$ & 41 & $(40 ; 43)$ & 0.6 & * & 41 & $(39 ; 43)$ & 43 & $(39 ; 48)$ & -0.1 & & 43 & $(37 ; 48)$ \\
\hline
\end{tabular}




\begin{tabular}{|c|c|c|c|c|c|c|c|c|c|c|c|}
\hline \multirow{3}{*}{ Malignancy } & \multirow{3}{*}{ Sex } & \multicolumn{5}{|c|}{ Wales } & \multicolumn{5}{|c|}{ Northern Ireland } \\
\hline & & \multicolumn{2}{|c|}{$\begin{array}{l}1996-99 \\
\text { complete }\end{array}$} & \multirow{2}{*}{$\begin{array}{l}\text { Annual \% } \\
\text { change }^{a}\end{array}$} & \multicolumn{2}{|c|}{$\begin{array}{c}2000-2001 \\
\text { hybrid }\end{array}$} & \multicolumn{2}{|c|}{$\begin{array}{c}1996-99 \\
\text { complete }\end{array}$} & \multirow{2}{*}{$\begin{array}{l}\text { Annual \% } \\
\text { change }^{\text {a }}\end{array}$} & \multicolumn{2}{|c|}{$\begin{array}{c}2000-2001 \\
\text { hybrid }\end{array}$} \\
\hline & & $R S$ & $(\mathrm{Cl})$ & & $R S$ & $(\mathrm{Cl})$ & $R S$ & $(C l)$ & & $R S$ & $(C l)$ \\
\hline \multirow[t]{2}{*}{ Oesophagus } & M & 10 & $(8 ; 13)$ & 0.8 & * 11 & $(8 ; 15)$ & 12 & $(7 ; 17)$ & 1.5 & 12 & $(7 ; 18)$ \\
\hline & $\mathrm{F}$ & & & & & & & & & & \\
\hline \multirow[t]{2}{*}{ Stomach } & M & 12 & $(10 ; 15)$ & 0.5 & 12 & $(10 ; 15)$ & 17 & $(13 ; 21)$ & 0.6 & 16 & $(12 ; 21)$ \\
\hline & $\mathrm{F}$ & 13 & $(10 ; 17)$ & 0.4 & 14 & $(11 ; 19)$ & & & & & \\
\hline \multirow[t]{2}{*}{ Colon } & M & 49 & $(46 ; 51)$ & 1.2 & * 48 & $(45 ; 52)$ & 56 & $(51 ; 60)$ & 2.6 & 55 & $(50 ; 60)$ \\
\hline & $\mathrm{F}$ & 46 & $(43 ; 48)$ & 1.3 & * 47 & $(43 ; 50)$ & 54 & $(51 ; 58)$ & 2.3 & * 54 & $(49 ; 58)$ \\
\hline \multirow[t]{2}{*}{ Rectum } & M & 45 & $(42 ; 49)$ & 1.0 & * 45 & $(41 ; 49)$ & 51 & $(45 ; 57)$ & 1.2 & 52 & $(45 ; 59)$ \\
\hline & $\mathrm{F}$ & 49 & $(44 ; 53)$ & 1.5 & * 49 & $(44 ; 54)$ & 49 & $(43 ; 56)$ & 1.3 & 49 & $(41 ; 56)$ \\
\hline \multirow[t]{2}{*}{ Pancreas } & M & 3 & $(2 ; 6)$ & -0.1 & 3 & $(2 ; 6)$ & 3 & $(1 ; 6)$ & ) $<-0.1$ & 2 & $(1 ; 7)$ \\
\hline & $\mathrm{F}$ & & & & & & 3 & $(1 ; 6)$ & & 3 & $(1 ; 8)$ \\
\hline Larynx & $M$ & 61 & $(53 ; 67)$ & -0.7 & 61 & $(51 ; 69)$ & & & & & \\
\hline \multirow[t]{2}{*}{ Lung } & M & 6 & $(5 ; 8)$ & 0.2 & 7 & $(6 ; 9)$ & 10 & $(8 ; 12)$ & 0.8 & 11 & $(9 ; 14)$ \\
\hline & $\mathrm{F}$ & 6 & $(5 ; 8)$ & 0.2 & 7 & $(5 ; 9)$ & & & & & \\
\hline \multirow{2}{*}{$\begin{array}{l}\text { Melanoma } \\
\text { of skin }\end{array}$} & $M$ & 67 & $(60 ; 73)$ & -0.7 & 68 & $(60 ; 75)$ & 89 & $(80 ; 94)$ & 0.2 & 86 & $(75 ; 92)$ \\
\hline & $\mathrm{F}$ & 84 & $(79 ; 89)$ & 0.6 & 83 & $(77 ; 88)$ & 96 & $(89 ; 98)$ & 0.7 & 94 & $(86 ; 97)$ \\
\hline Breast & $F$ & 78 & $(76 ; 79)$ & 0.6 & * 78 & $(77 ; 80)$ & 80 & $(78 ; 82)$ & 1.1 & * 82 & $(79 ; 84)$ \\
\hline Cervix & $\mathrm{F}$ & 55 & $(51 ; 60)$ & -0.9 & 56 & $(50 ; 61)$ & 71 & $(64 ; 76)$ & 2.5 & 72 & $(63 ; 79)$ \\
\hline Uterus & $F$ & 74 & $(70 ; 77)$ & $<-0.1$ & 73 & $(68 ; 77)$ & 76 & $(69 ; 81)$ & 1.6 & 77 & $(68 ; 83)$ \\
\hline Ovary & $F$ & 35 & $(32 ; 38)$ & 1.2 & * 35 & $(31 ; 38)$ & & & & & \\
\hline Prostate & M & 64 & $(61 ; 66)$ & 2.2 & * 66 & $(63 ; 69)$ & 60 & $(55 ; 63)$ & 0.7 & 63 & $(58 ; 68)$ \\
\hline Testis & M & 96 & $(92 ; 98)$ & 1.7 & * 97 & $(91 ; 99)$ & 95 & $(88 ; 98)$ & 0.8 & 96 & $(87 ; 99)$ \\
\hline \multirow[t]{2}{*}{ Bladder } & M & 73 & $(70 ; 76)$ & 0.5 & 75 & $(70 ; 78)$ & 67 & $(60 ; 73)$ & 2.0 & 66 & $(57 ; 73)$ \\
\hline & $\mathrm{F}$ & 65 & $(61 ; 70)$ & 1.7 & * 66 & $(60 ; 71)$ & 52 & $(43 ; 60)$ & 4.1 & 44 & $(34 ; 55)$ \\
\hline \multirow{2}{*}{$\begin{array}{l}\text { Bladder includ. } \\
\text { non-malignant }\end{array}$} & M & 75 & $(71 ; 77)$ & 0.4 & 76 & $(72 ; 79)$ & 79 & $(74 ; 83)$ & 0.9 & 77 & $(70 ; 82)$ \\
\hline & $\mathrm{F}$ & 69 & $(65 ; 73)$ & 1.9 & * 68 & $(63 ; 73)$ & 68 & $(61 ; 74)$ & 2.3 & 63 & $(54 ; 71)$ \\
\hline \multirow[t]{2}{*}{ Kidney } & M & 47 & $(42 ; 52)$ & 0.7 & 50 & $(43 ; 56)$ & 55 & $(48 ; 62)$ & 1.2 & 56 & $(46 ; 65)$ \\
\hline & $\mathrm{F}$ & 46 & $(40 ; 52)$ & 1.6 & 48 & $(40 ; 55)$ & 49 & $(40 ; 56)$ & -1.3 & 48 & $(37 ; 58)$ \\
\hline \multirow[t]{2}{*}{ Brain } & M & 11 & $(8 ; 15)$ & -0.7 & 13 & $(9 ; 19)$ & & & & & \\
\hline & $\mathrm{F}$ & & & & & & 18 & $(10 ; 27)$ & -1.3 & 19 & $(10 ; 31)$ \\
\hline \multirow{2}{*}{$\begin{array}{l}\text { Non-Hodgkin } \\
\text { lymphoma }\end{array}$} & M & 46 & $(41 ; 50)$ & $<-0.1$ & 50 & $(44 ; 56)$ & & & & & \\
\hline & $\mathrm{F}$ & 48 & $(43 ; 52)$ & -0.3 & 49 & $(43 ; 55)$ & 48 & $(42 ; 55)$ & -0.7 & 51 & $(43 ; 59)$ \\
\hline \multirow{2}{*}{$\begin{array}{l}\text { Multiple } \\
\text { myeloma }\end{array}$} & M & 23 & $(16 ; 31)$ & -1.1 & 26 & $(17 ; 35)$ & 26 & $(18 ; 35)$ & 0.6 & 30 & $(19 ; 42)$ \\
\hline & $\mathrm{F}$ & 24 & $(17 ; 32)$ & 0.6 & 24 & $(16 ; 34)$ & & & & & \\
\hline \multirow[t]{2}{*}{ All leukaemias } & M & 40 & $(36 ; 45)$ & 1.0 & 42 & $(36 ; 48)$ & 26 & $(19 ; 34)$ & -1.6 & 26 & $(17 ; 35)$ \\
\hline & $\mathrm{F}$ & 38 & $(32 ; 43)$ & -0.4 & 39 & $(33 ; 45)$ & 31 & $(23 ; 39)$ & -2.0 & 29 & $(20 ; 39)$ \\
\hline
\end{tabular}




\begin{tabular}{|c|c|c|c|c|c|c|c|c|c|c|c|c|c|c|c|c|}
\hline \multirow{3}{*}{ Malignancy } & \multirow{3}{*}{ Sex } & \multicolumn{5}{|c|}{ United Kingdom } & \multicolumn{5}{|c|}{ Republic of Ireland } & \multicolumn{5}{|c|}{ UK and R Ireland } \\
\hline & & \multicolumn{2}{|c|}{$\begin{array}{l}1996-99 \\
\text { complete }\end{array}$} & \multirow{2}{*}{$\begin{array}{l}\text { Annual \% } \\
\text { change }^{\text {b }}\end{array}$} & \multicolumn{2}{|c|}{$\begin{array}{c}2000-2001 \\
\text { hybrid }\end{array}$} & \multicolumn{2}{|c|}{$\begin{array}{l}1996-99 \\
\text { complete }\end{array}$} & \multirow{2}{*}{$\begin{array}{l}\text { Annual \% } \\
\text { change }^{\mathrm{a}}\end{array}$} & \multicolumn{2}{|c|}{$\begin{array}{c}\% 2000-2001 \\
\text { hybrid }\end{array}$} & \multicolumn{2}{|c|}{$\begin{array}{l}1996-99 \\
\text { complete }\end{array}$} & \multicolumn{3}{|c|}{ 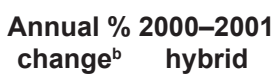 } \\
\hline & & $R S$ & $(C l)$ & & $R S$ & $(\mathrm{Cl})$ & $R S$ & $(C l)$ & & $R S$ & $(C l)$ & $R S$ & $(C l)$ & & $R S$ & $(C l)$ \\
\hline \multirow[t]{2}{*}{ Oesophagus } & M & 8 & $(8 ; 9)$ & 0.4 & * & $(8 ; 10)$ & 11 & $(8 ; 14)$ & 0.2 & 11 & $(7 ; 15)$ & 8 & $(8 ; 9)$ & 0.4 & * 9 & $(8 ; 10)$ \\
\hline & $\mathrm{F}$ & 8 & $(7 ; 9)$ & $<-0.1$ & 8 & $(7 ; 9)$ & 13 & $(9 ; 17)$ & & 13 & $(8 ; 19)$ & 8 & $(7 ; 9)$ & $<-0.1$ & 8 & $(8 ; 9)$ \\
\hline \multirow[t]{2}{*}{ Stomach } & M & 14 & $(13 ; 14)$ & 0.5 & * 14 & $(13 ; 15)$ & & & & & & 14 & $(13 ; 14)$ & 0.6 & * 14 & $(13 ; 15)$ \\
\hline & $\mathrm{F}$ & 15 & $(14 ; 15)$ & 0.5 & * 15 & $(14 ; 16)$ & 19 & $(15 ; 23)$ & 0.5 & 18 & $(13 ; 23)$ & 15 & $(14 ; 16)$ & 0.6 & * 15 & $(14 ; 16)$ \\
\hline \multirow[t]{2}{*}{ Colon } & M & 49 & $(48 ; 50)$ & 1.1 & * 50 & $(49 ; 51)$ & 51 & $(48 ; 54)$ & 1.3 & 51 & $(47 ; 54)$ & 49 & $(49 ; 50)$ & 1.1 & * 50 & $(50 ; 51)$ \\
\hline & $\mathrm{F}$ & 48 & $(48 ; 49)$ & 1.1 & * 50 & $(49 ; 50)$ & 53 & $(51 ; 56)$ & 1.7 & * 56 & $(52 ; 59)$ & 49 & $(48 ; 49)$ & 1.1 & * 50 & $(49 ; 51)$ \\
\hline \multirow[t]{2}{*}{ Rectum } & M & 51 & $(50 ; 51)$ & 1.8 & * 52 & $(51 ; 53)$ & 48 & $(45 ; 52)$ & 2.5 & * 51 & $(47 ; 55)$ & 50 & $(50 ; 51)$ & 1.8 & * 52 & $(51 ; 53)$ \\
\hline & $\mathrm{F}$ & 51 & $(50 ; 52)$ & 1.5 & * 52 & $(51 ; 53)$ & 50 & $(45 ; 54)$ & -1.0 & 53 & $(47 ; 58)$ & 51 & $(50 ; 52)$ & 1.4 & * 52 & $(51 ; 53)$ \\
\hline \multirow[t]{2}{*}{ Pancreas } & $\mathrm{M}$ & 3 & $(3 ; 3)$ & 0.1 & 3 & $(3 ; 4)$ & 4 & $(3 ; 7)$ & 0.1 & 5 & $(3 ; 8)$ & 3 & $(3 ; 3)$ & 0.1 & 3 & $(3 ; 4)$ \\
\hline & $\mathrm{F}$ & 2 & $(2 ; 3)$ & $<-0.1$ & 2 & $(2 ; 3)$ & 6 & $(4 ; 8)$ & -0.1 & 7 & $(4 ; 10)$ & 3 & $(2 ; 3)$ & $<-0.1$ & 3 & $(2 ; 3)$ \\
\hline Larynx & M & 66 & $(64 ; 68)$ & 0.4 & 66 & $(64 ; 68)$ & 67 & $(59 ; 73)$ & 2.5 & 64 & $(54 ; 71)$ & 66 & $(64 ; 68)$ & 0.5 & * 66 & $(64 ; 68)$ \\
\hline \multirow[t]{2}{*}{ Lung } & $M$ & 7 & $(6 ; 7)$ & 0.2 & * 7 & $(6 ; 7)$ & 8 & $(7 ; 9)$ & -0.3 & 8 & $(7 ; 10)$ & 7 & $(6 ; 7)$ & 0.2 & * 7 & $(7 ; 7)$ \\
\hline & $\mathrm{F}$ & 7 & $(7 ; 7)$ & 0.3 & * & $(7 ; 8)$ & 9 & $(8 ; 11)$ & -0.4 & 10 & $(8 ; 12)$ & 7 & $(7 ; 8)$ & 0.3 & * 8 & $(7 ; 8)$ \\
\hline \multirow{2}{*}{$\begin{array}{l}\text { Melanoma } \\
\text { of skin }\end{array}$} & M & 81 & $(79 ; 82)$ & 0.9 & * 81 & $(80 ; 83)$ & 73 & $(67 ; 78)$ & -0.8 & 73 & $(66 ; 79)$ & 80 & $(79 ; 81)$ & 0.8 & * 81 & $(79 ; 82)$ \\
\hline & $\mathrm{F}$ & 91 & $(90 ; 92)$ & 0.6 & * 91 & $(90 ; 92)$ & 90 & $(86 ; 93)$ & 0.7 & 91 & $(87 ; 94)$ & 91 & $(90 ; 92)$ & 0.6 & * 91 & $(90 ; 92)$ \\
\hline Breast & $\mathrm{F}$ & 80 & $(80 ; 81)$ & 1.0 & * 81 & $(81 ; 82)$ & 77 & $(75 ; 78)$ & 1.4 & * 78 & $(76 ; 80)$ & 80 & $(80 ; 81)$ & 1.0 & * 81 & $(81 ; 82)$ \\
\hline Cervix & $\mathrm{F}$ & 67 & $(66 ; 68)$ & 0.3 & 67 & $(66 ; 69)$ & 68 & $(63 ; 72)$ & 2.6 & * 71 & $(65 ; 76)$ & 67 & $(66 ; 68)$ & 0.3 & * 68 & $(66 ; 69)$ \\
\hline Uterus & $\mathrm{F}$ & 77 & $(76 ; 78)$ & 0.7 & * 78 & $(76 ; 79)$ & 80 & $(77 ; 84)$ & 2.9 & * 80 & $(75 ; 84)$ & 77 & $(76 ; 78)$ & 0.8 & * 78 & $(77 ; 79)$ \\
\hline Ovary & $\mathrm{F}$ & 39 & $(38 ; 40)$ & 1.6 & * 40 & $(39 ; 41)$ & 41 & $(38 ; 45)$ & -0.6 & 43 & $(38 ; 47)$ & 39 & $(38 ; 40)$ & 1.5 & * 40 & $(39 ; 41)$ \\
\hline Prostate & M & 72 & $(72 ; 73)$ & 3.0 & * 74 & $(73 ; 75)$ & 73 & $(70 ; 75)$ & 3.8 & * 77 & $(74 ; 79)$ & 72 & $(72 ; 73)$ & 3.0 & * 74 & $(73 ; 75)$ \\
\hline Testis & M & 96 & $(96 ; 97)$ & 0.5 & * 97 & $(96 ; 97)$ & & & & & & 96 & $(95 ; 97)$ & 0.4 & * 96 & $(96 ; 97)$ \\
\hline \multirow[t]{2}{*}{ Bladder } & M & 69 & $(68 ; 70)$ & 0.1 & 69 & $(68 ; 70)$ & 74 & $(69 ; 78)$ & $<-0.1$ & 75 & $(69 ; 80)$ & 69 & $(68 ; 70)$ & 0.1 & 69 & $(68 ; 70)$ \\
\hline & $F$ & 57 & $(56 ; 58)$ & -0.4 & * 57 & $(55 ; 58)$ & 69 & $(63 ; 74)$ & 0.7 & 69 & $(61 ; 76)$ & 58 & $(56 ; 59)$ & -0.4 & * 57 & $(56 ; 59)$ \\
\hline \multirow{2}{*}{$\begin{array}{l}\text { Bladder includ. } \\
\text { non-malignant }\end{array}$} & $M$ & 70 & $(70 ; 71)$ & 0.2 & 70 & $(69 ; 71)$ & 75 & $(71 ; 79)$ & 0.3 & 78 & $(72 ; 82)$ & 71 & $(70 ; 71)$ & 0.2 & 70 & $(69 ; 71)$ \\
\hline & $\mathrm{F}$ & 59 & $(58 ; 60)$ & -0.3 & 59 & $(58 ; 61)$ & 70 & $(64 ; 75)$ & 0.8 & 71 & $(63 ; 78)$ & 60 & $(59 ; 61)$ & -0.2 & 60 & $(58 ; 61)$ \\
\hline Kidney & $M$ & 48 & $(46 ; 49)$ & 0.8 & * 49 & $(47 ; 50)$ & 49 & $(43 ; 54)$ & -0.9 & 48 & $(42 ; 55)$ & 48 & $(46 ; 49)$ & 0.8 & * 49 & $(47 ; 50)$ \\
\hline & $\mathrm{F}$ & 47 & $(45 ; 48)$ & 1.2 & * 47 & $(46 ; 49)$ & 53 & $(46 ; 59)$ & -0.2 & 53 & $(44 ; 61)$ & 47 & $(45 ; 48)$ & 1.2 & * 48 & $(46 ; 49)$ \\
\hline Brain & $M$ & 13 & $(12 ; 14)$ & -0.2 & 13 & $(12 ; 14)$ & 21 & $(17 ; 25)$ & 1.1 & 21 & $(16 ; 26)$ & 13 & $(13 ; 14)$ & -0.1 & 13 & $(12 ; 14)$ \\
\hline & $\mathrm{F}$ & 15 & $(14 ; 16)$ & -0.1 & 14 & $(13 ; 16)$ & 20 & $(16 ; 25)$ & & 20 & $(14 ; 27)$ & 15 & $(14 ; 16)$ & $<-0.1$ & 15 & $(13 ; 16)$ \\
\hline & $M$ & 53 & $(52 ; 54)$ & 1.1 & * 55 & $(53 ; 56)$ & 52 & $(48 ; 56)$ & 1.2 & 54 & $(49 ; 60)$ & 53 & $(52 ; 54)$ & 1.1 & * 55 & $(53 ; 56)$ \\
\hline & $\mathrm{F}$ & 54 & $(53 ; 55)$ & 0.8 & * 55 & $(54 ; 56)$ & 57 & $(53 ; 62)$ & 0.5 & 58 & $(52 ; 64)$ & 54 & $(53 ; 55)$ & 0.8 & * 55 & $(54 ; 56)$ \\
\hline & M & 29 & $(27 ; 31)$ & 1.2 & * 30 & $(28 ; 32)$ & 26 & $(20 ; 32)$ & 1.8 & 24 & $(17 ; 31)$ & 29 & $(27 ; 30)$ & 1.2 & * 29 & $(27 ; 31)$ \\
\hline & $\mathrm{F}$ & 28 & $(26 ; 29)$ & 1.2 & * 28 & $(26 ; 30)$ & 26 & $(20 ; 34)$ & 0.3 & 23 & $(16 ; 31)$ & 28 & $(26 ; 29)$ & 1.2 & * 28 & $(26 ; 30)$ \\
\hline All leukaemias & M & 45 & $(44 ; 46)$ & 1.1 & * 45 & $(43 ; 47)$ & 44 & $(38 ; 49)$ & 0.5 & 43 & $(36 ; 49)$ & 45 & $(43 ; 46)$ & 1.1 & * 45 & $(43 ; 46)$ \\
\hline & $\mathrm{F}$ & 41 & $(40 ; 42)$ & 0.4 & * 41 & $(39 ; 43)$ & 49 & $(43 ; 54)$ & 0.6 & 47 & $(40 ; 54)$ & 41 & $(40 ; 43)$ & 0.5 & * 41 & $(40 ; 43)$ \\
\hline
\end{tabular}

${ }^{a}$ Annual absolute percentage change calculated by dividing the absolute difference in survival between 1991-95 and 1996-99 by the number of years between the mid-point of each calendar period. Figures take into account the slightly shorter periods of diagnosis available for Northern Ireland (1993-95) and the Republic of Ireland (1994-95).

${ }^{b}$ Incident cancer cases were collected from 1993 in Northern Ireland and from 1994 in the Republic of Ireland. However, in order to produce a single UK-wide estimate of the annual percentage change, it was necessary to assume that all countries provided data from 1991.

$* p<0.05$

Blank cells indicate that five-year survival could not be estimated. This occurs in cases where the population is very small, or when the cancer is particularly lethal. 
Figure 2a Range in one-year relative survival (\%) by country, for (a) cancers with good prognosis (one-year survival $50 \%$ or higher) and (b) cancers with poor prognosis (one-year survival less than $50 \%$ ): patients diagnosed in the UK and Republic of Ireland 1996-99

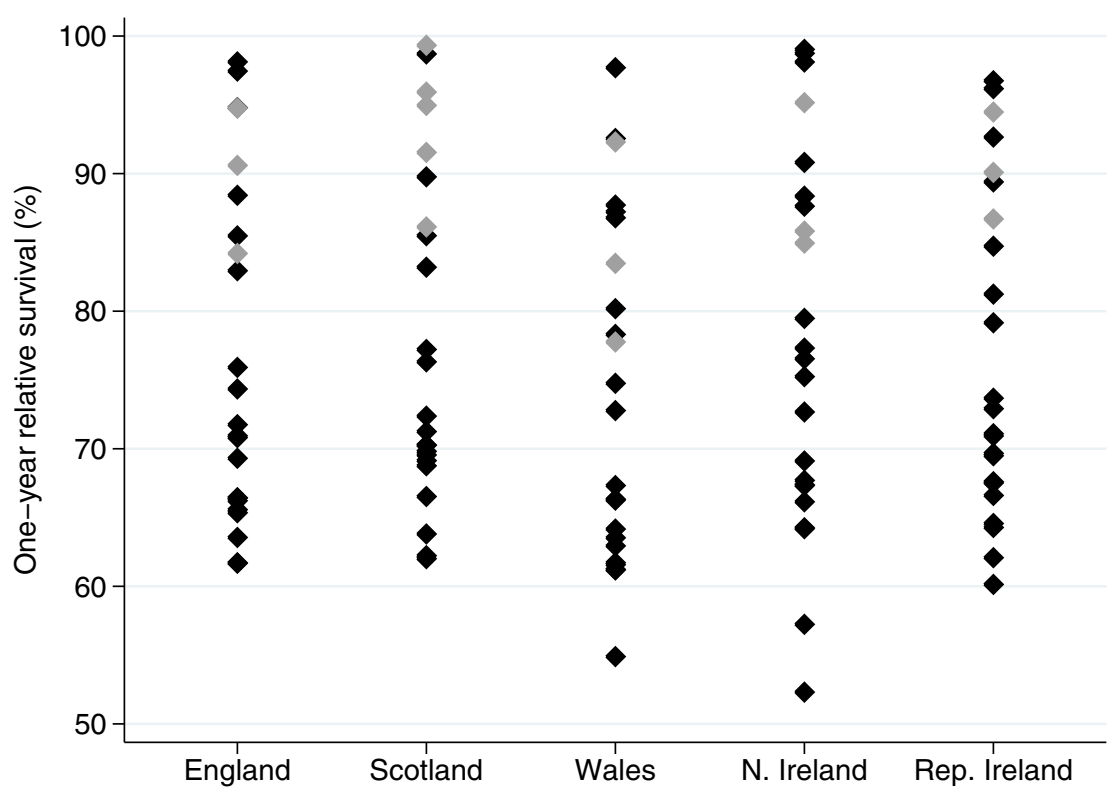

Figure $2 b$

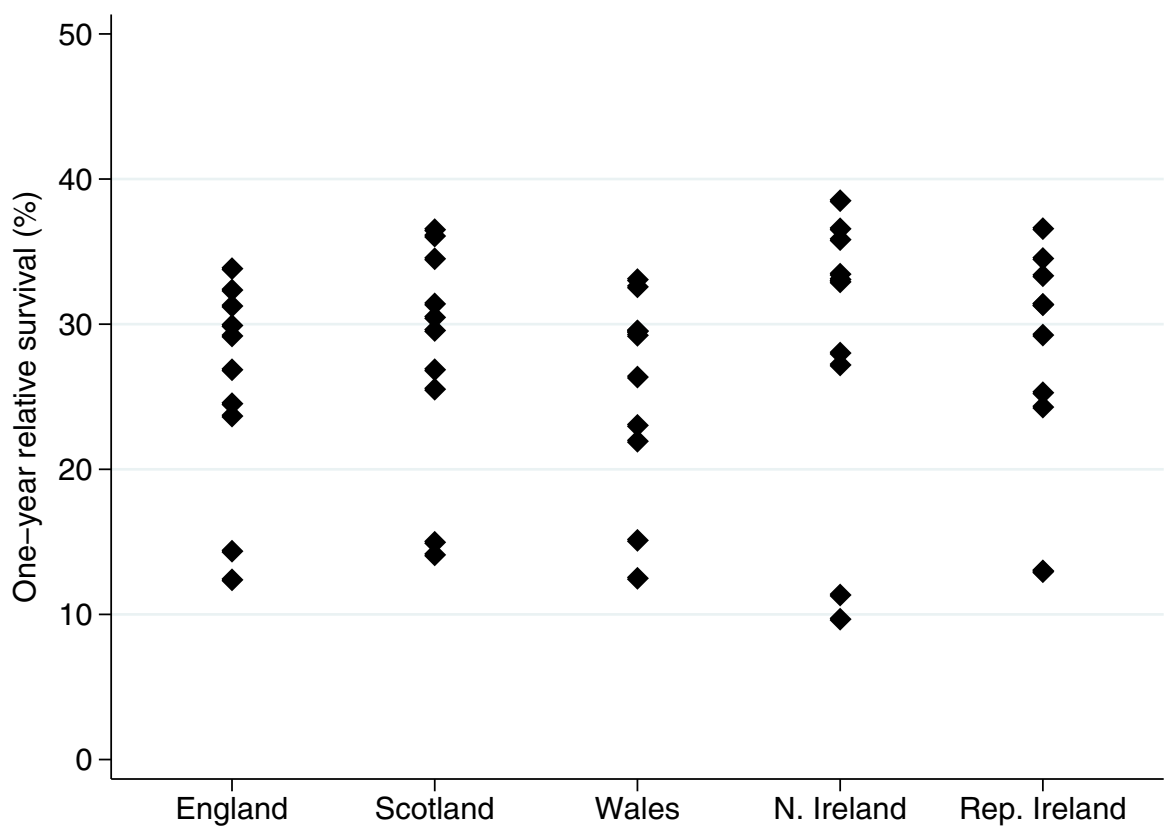

Grey data points indicate cancers for which active early detection programmes were in place during this period (breast, prostate, cervix and, in Scotland, melanoma). 
Figure 3 Funnel plots showing the geographical variation in oneyear relative survival for patients diagnosed during 199699 in the UK and Republic of Ireland: selected cancers
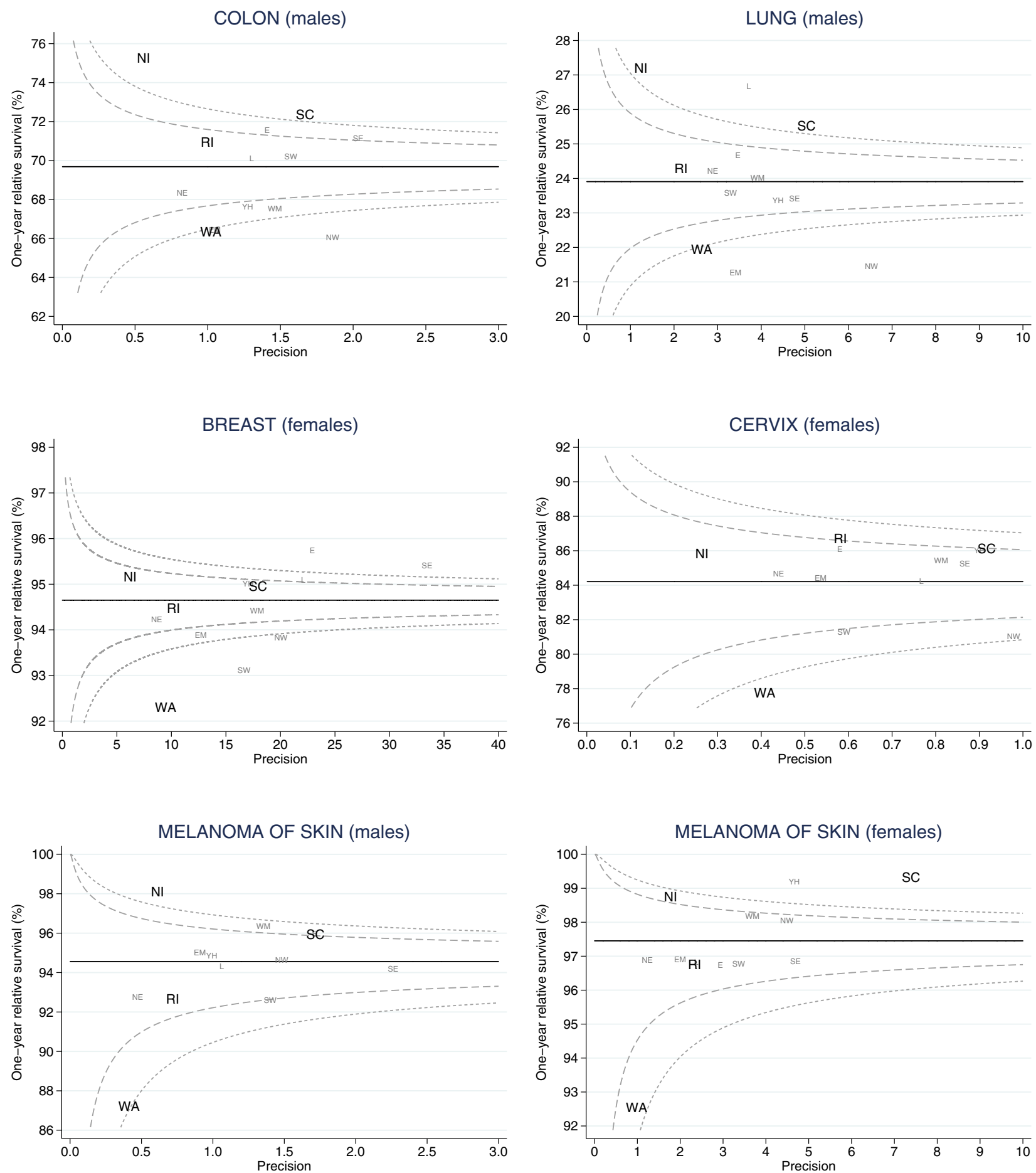

In each case the horizontal line indicates the estimate for the UK and Republic of Ireland combined with $95 \%$ (inner) and 99.8\% (outer) confidence intervals.

UK - United Kingdom, EN - England, NI - Northern Ireland, RI - Republic of Ireland, SC - Scotland, WA Wales; E - Eastern, EM - East Midlands, L - London, NE - North East, NW - North West, SE - South East, SW - South West, WM - West Midlands, YH -Yorkshire and Humber. 
The pathological classification and coding of bladder tumours changed markedly during the 1990s, and this had a substantial effect on survival estimates. The proportion of tumours coded as in situ (behaviour code 2) or uncertain if benign or malignant (code 1) increased from three per cent in 1991 to more than seven per cent in 1999 in the data as a whole, with the percentage in any given year in the separate countries ranging from less than 1 per cent in Scotland during the years 199193 to greater than 50 per cent in Northern Ireland in 1993. In situ bladder tumours have very high survival and are routinely excluded from survival estimates for invasive bladder cancers. The data for bladder cancer were analysed both with and without these tumours. Inclusion of bladder cancer classified as in situ or of uncertain malignancy led to higher survival estimates in all countries and regions, and it substantially changed the estimates for Northern Ireland (Table 2), and the Eastern region of England (Supplementary Table 4). Given the extreme geographic and temporal variation in the behaviour coded for bladder cancers in the UK and the Republic of Ireland, we judged that survival estimates including tumours coded as in situ or of uncertain malignancy were more comparable, and those results are presented here.

Annual increases in relative survival were greatest in England, Northern Ireland and the Republic of Ireland and smallest in Wales and Scotland. The largest overall improvements were observed for cancers of the colon, rectum and prostate. Decreasing or stable survival rates were also observed, but the only observed decline that was statistically significant at the 5 per cent level was that for bladder cancer in Scotland and in England for females: this trend was seen both with and without non-invasive malignancies.

Among patients diagnosed during 1996-99, five-year survival tended to be higher in the Republic of Ireland and Northern Ireland and lower in England and Wales. However, this pattern varied by cancer site. International differences were greatest for cancers of the colon, cervix, prostate, bladder and brain, for melanoma of the skin, multiple myeloma and all the leukaemias combined, whilst differences were smallest for cancers of the stomach, pancreas, breast, uterus, testis and kidney, and for non-Hodgkin lymphoma. Northern Ireland displayed the widest range in survival between different cancers, as would be expected for the country with the smallest population. Despite their smaller populations, Scotland and the Republic of Ireland displayed a similar range of survival to that seen in England, both for cancers with moderate or good prognosis (one-year survival greater than 50 per cent, Figure 2(a)) and for cancers with poorer prognosis (one-year survival less than 50 per cent, Figure 2(b)). Survival tended to be higher in Scotland for cancers for which screening or other early detection methods were in place during this period (breast, cervix, prostate and, in Scotland, melanoma).

There was geographic variation in one-year survival for most cancers in both sexes (Figure 3, Supplementary Figure 2). There was also some significant regional variation within England. Oneyear survival for melanoma was significantly higher in Scotland and in Northern Ireland than in the regions of England, the Republic of Ireland or Wales. There was also substantial variation in oneyear survival from prostate and bladder cancers. The least variation was observed for cancers of the kidney, pancreas, brain, testis and uterus.

Survival tended to be lower in the northern regions of England and higher in the southern regions (Supplementary Figure 1, Supplementary Tables 3 and 4). The largest regional variation was 
observed for multiple myeloma, all leukaemias combined, bladder, kidney and brain, while regional variation was least marked for cancers of the breast, pancreas, uterus and testis, and melanoma of the skin.

The proportion of cases with a recorded survival of zero was higher in England (particularly in the Thames region, about 25 per cent of the English population) than in Scotland, Northern Ireland or the Republic of Ireland. We therefore re-analysed the English data excluding cases from the Thames Cancer Registry. This slightly reduced the survival estimates for England.

\section{Discussion}

We have shown that the prognosis for patients diagnosed with one of the twenty most common cancers improved between the early and late 1990s in the four constituent countries of the UK and in the Republic of Ireland, and that the survival of patients diagnosed in Scotland and Ireland was generally higher than in England and Wales. Regional variations were also evident in England.

It is important to evaluate the possible role of artefact in explaining differences in cancer survival. Survival will be over-estimated if the linkage of death notifications with registered cancer cases is inefficient. However, we consider it unlikely that variation in the completeness of this linkage between the various national cancer registries is sufficient of itself to explain fully the geographic patterns of survival. Each registry regularly links its cancer patient data to data on deaths occurring in the same country in order to determine which patients have died, and when. The death of a registered cancer patient may be missed if they moved from one country to another after cancer diagnosis. The impact of such migration on survival estimates is likely to be very small: linkages for England and Wales are performed on a single database and regular cross-checks are carried out with the database for Scotland.

Survival is also sensitive to the proportion of 'zero survival' cases excluded from analysis. This category generally includes both patients with 'true' zero survival, who are known to have died on the day of diagnosis and whose cancer registration record reflects that fact, and patients who were registered only from a death certificate (DCO registrations), and for whom the date of diagnosis and the duration of survival are thus unknown. Both categories were excluded from analysis, because they were not distinguishable in the datasets analysed. Patients whose cancer was registered as a DCO tend to have had shorter survival than patients who were registered in life (Berrino et al. 1995). A high proportion of zero survival cases excluded from analysis may therefore lead to inflation of the survival estimate. In this study, England and Wales had the highest proportion of zero survival cases, but generally lower survival. In a sensitivity analysis in which the registry with the highest proportion of zero survival cases was excluded, the differences in survival between England and the other countries increased, rather than declined. Differences in the proportion of zero survival cases are therefore unlikely to explain why survival in England and Wales is generally lower than in Scotland, Northern Ireland or the Republic of Ireland.

Estimation of survival may also be influenced by the accuracy and comparability of the rules used to establish the date of diagnosis. For any given patient, several points on the diagnostic pathway could have been used to determine the point of diagnosis, for example, the day of first reported 
symptoms, the day of biopsy, the day of a confirmatory laboratory test, or the first day of treatment. During the period in question, the date of diagnosis was defined slightly differently by the five national cancer registries. This may have led to small artefactual differences in survival. The greatest differences are likely to be between Scotland, which always used the earliest date available, and the other four nations, where the date of the event with the highest priority was used. This may have slightly inflated the estimates for Scotland in comparison to the other parts of the UK or Republic of Ireland, particularly for short-term survival and for lethal cancers. Differences in selection of the date of diagnosis do bias survival estimates up to a year after diagnosis (Dickman \& Hakulinen 1997), but the impact is much smaller than the geographical differences observed here.

The variations in survival could in theory be due to confounding by age, since relative survival varies with age, and the age profile of cancer patients can differ between populations. Age standardisation would have minimised differences in survival due to these factors. It was not possible to perform comparable age standardisation for all datasets here, but where both types of analysis were feasible, differences between the standardised and non-standardised estimates were small, and variations in survival between the five countries were still evident (data not shown).

It is conceivable that a higher proportion of tumours registered in Scotland, Northern Ireland and the Republic of Ireland are, in fact, in situ than is the case in England and Wales. This is unlikely to explain the observed differences in full, because the proportion of tumours verified microscopically is highest in Scotland and in the Republic of Ireland, similar in Northern Ireland and England, with Wales having a much lower proportion (Curado et al. 2007; Personal communication to LM Woods from C White, received 20 May 2009). This suggests that, if anything, the proportion of in situ cases misclassified as invasive, and therefore artificial inflations in survival, are likely to be greatest in England, Wales and Northern Ireland.

Scotland and Northern Ireland had especially high relative survival from melanoma. This is likely to be due to a combination of active campaigns of earlier detection (Mackie \& Hole 1992), and better ascertainment of thin lesions, which have a good prognosis. Better ascertainment of such tumours in Scotland has been suggested by a previous audit study of patients diagnosed during 1987-89 in seven health districts in England and one health board in Scotland (Melia et al. 1995). The high completeness of registration in Scotland probably reflects the close working relationship between the Scottish Cancer Registry and the Scottish Melanoma Group, which runs a specialist tumour registry. Lower melanoma survival in Wales may be due either to later diagnosis than in the other countries (patients in Wales would have thicker tumours) or because treatment in Wales is not as good (distribution of tumour thickness would be similar to that in other countries). The Welsh Cancer Intelligence Unit is currently working with dermatologists to obtain more detailed data on tumour thickness.

Although the variations in survival between the UK nations and the Republic of Ireland are not as great as those observed globally (Coleman et al. 2008) or within Europe (Berrino et al. 2007), there appears to be an overall pattern of lower survival in England and Wales than in the other countries. Three broad causal explanations for this difference in survival may be considered. First, delays in diagnosis may be shorter, patients present at an earlier stage of disease in Scotland, Northern 
Ireland and the Republic of Ireland than in England or Wales. Second, access to diagnosis investigations and treatment and/or the quality or organisation of cancer care services may be better in Scotland and Ireland. Third, the underlying characteristics of the cancer patient population may differ in such a way that treatment is more effective in Scotland and Ireland. To evaluate these hypotheses, it would be necessary to obtain more detailed information on pre-diagnosis symptoms, tumour stage at diagnosis, diagnostic tests performed, treatment received and co-morbidity than are routinely captured by the national cancer registry in each country. Such information could be used to examine the impact of delay, treatment, co-morbidity and cancer control policy parameters upon differences in cancer patient survival between the UK nations and the Republic of Ireland. Such detailed information has recently become available in all the UK countries and the Republic of Ireland.

\section{Conclusion}

This paper reports cancer survival comparisons between the countries of the UK, the regions of England and the Republic of Ireland for the twenty most common malignancies. We have documented lower cancer survival in England and Wales than in Scotland, Northern Ireland and the Republic of Ireland. Cancer survival in the UK and the Republic of Ireland improved during the 1990s. By the end of the twentieth century there was still geographic variation in survival across the UK and the Republic of Ireland, with the lowest survival in the North of England: regional differences in survival within England are often wider than the differences between the five countries. Despite standardised treatment protocols in England, survival has generally been lower than in Scotland, Northern Ireland and the Republic of Ireland. Artefact is only likely to explain a small component of these differences. Geographic differences in stage at diagnosis, co-morbidity and other clinical factors may also be relevant, particularly if they influence the clinical decision to provide more effective but more aggressive treatment.

\section{Acknowledgements}

We gratefully acknowledge the work of our colleagues in the cancer registries of the UK and the Republic of Ireland who collected the original cancer patient data. We are grateful to Diane Stockton for her advice and input on these analyses. Death certificate data for the Republic of Ireland were provided by the Central Statistics Office, Dublin.

\section{Funding}

This work was supported by Cancer Research UK [grant numbers C1336/A2990 and C1336/A4014]. 


\section{References}

Berrino, F., De Angelis, R., Sant, M., Rosso, S., Bielska-Lasota, M., Coebergh, J. W., \& Santaquilani, M. (2007), "Survival for eight major cancers and all cancers combined for European adults diagnosed in 1995-99: results of the EUROCARE-4 study", Lancet Oncology, vol. 8, no. 9, pp. 773-783.

Berrino, F., Sant, M., Verdecchia, A., Capocaccia, R., Hakulinen, T., \& Estève, J. Survival of cancer patients in Europe: the EUROCARE study. 1995. Lyon, International Agency for Research on Cancer. IARC Scientific Publications No. 132.

Brenner, H. \& Rachet, B. (2004), "Hybrid analysis for up-to-date long-term survival rates in cancer registries with delayed recording of incident cases", European Journal of Cancer, vol. 40, no. 16, pp. 2494-2501.

Central Statistics Office (1995), Irish Life Table No. 12 1990-92, Central Statistics Office, Dublin \& Cork.

Central Statistics Office (2004), Irish Life Table No. 14 2001-03, Central Statistics Office, Dublin \& Cork.

Coleman, M. P., Babb, P., Damiecki, P., Grosclaude, P., Honjo, S., Jones, J., Knerer, G., Pitard, A., Quinn, M. J., Sloggett, A., \& De Stavola, B. L. (1999), Cancer survival trends in England and Wales 1971-1995: deprivation and NHS Region. Series SMPS No. 61 The Stationery Office, London.

Coleman, M. P., Quaresma, M., Berrino, F., Lutz, J. M., De Angelis, R., Capocaccia, R., Baili, P., Rachet, B., Gatta, G., Hakulinen, T., Micheli, A., Sant, M., Weir, H. K., Elwood, J. M., Tsukuma, H., Koifman, S., Silva, G. A., Francisci, S., Santaquilani, M., Verdecchia, A., Storm, H. H., \& Young, J. L. (2008), "Cancer survival in five continents: a worldwide population-based study (CONCORD)", Lancet Oncology, vol. 9, no. 8, pp. 730-756

Coleman, M. P., Rachet, B., Woods, L. M., Mitry, E., Riga, M., Cooper, N., Quinn, M. J., Brenner, H., \& Estève, J. (2004), "Trends and socioeconomic inequalities in cancer survival in England and Wales up to 2001", British Journal of Cancer, vol. 90, no. 7, pp. 1367-1373.

Comber, H. \& Walsh, P. (2008), Patterns of care and survival of cancer patients in Ireland 1994 to 2004, National Cancer Registry, Cork.

Curado, M. P., Edwards, B., Shin, H. R., Storm, H., Ferlay, J., Heanue, M., \& Boyle, P. Cancer incidence in five continents, volume IX. 2007. Lyon, International Agency for Research on Cancer. IARC Scientific Publications No. 160. 
Dickman, P. W. \& Hakulinen, T. (1997), "The accuracy of index dates and calculation of survival time from cancer registry data", Journal of Epidemiology and Biostatistics, vol. 2, pp. 87-94.

Ederer, F., Axtell, L. M., \& Cutler, S. J. (1961), "The relative survival: a statistical methodology", National Cancer Institute Monographs, vol. 6, pp. 101-121.

Estève, J., Benhamou, E., Croasdale, M., \& Raymond, L. (1990), "Relative survival and the estimation of net survival: elements for further discussion", Statistics in Medicine, vol. 9, pp. 529538.

Ewbank, D. C., Gomez de Leon, J. C., \& Stoto, M. A. (1983), "A reducible four-parameter system of model life tables", Population Studies, vol. 37, pp. 105-127.

Government Actuary's Department (2004) Interim life tables. http://www.gad.gov.uk accessed $7 / 8 / 08$.

Mackie, R. M. \& Hole, D. (1992), "Audit of public education campaign to encourage earlier detection of malignant melanoma", British Medical Journal, vol. 304, no. 6833, pp. 1012-1015.

Melia, J., Frost, T., Graham-Brown, R., Hunter, J., Marsden, A., du, V. A., Warin, A. P., White, J., Whitehead, S., \& Wroughton, M. (1995), "Problems with registration of cutaneous malignant melanoma in England", British Journal of Cancer, vol. 72, no. 1, pp. 224-228.

Northern Ireland Cancer Registry (2007), Survival of cancer patients in Northern Ireland: 1993-04, Queen's University Belfast, Belfast.

Scottish Cancer Intelligence Unit (2000), Trends in cancer survival in Scotland 1971-95, Information and Statistics Division, Edinburgh.

Spiegelhalter, D. J. (2005), "Funnel plots for comparing institutional performance", Statistics in Medicine, vol. 24, no. 8, pp. 1185-1202. 